\title{
DHURDHURAPATRADI MALAHARA: AN INDIAN MEDICINE FOR DANDRUFF
}

\author{
*Krishnaprriya \\ *PG Scholar, Dept of RS and BK, Amrita School of Ayurveda, Amritapuri, Clappana P.O, \\ Vallickavu ,Kollam ,Kerala- 690525 \\ **Kamath Mahusudana \\ Former Associate Professor, Division of Ayurveda, Centre for Integrative Medicine and Research \\ Manipal Academy of Higher Education, Manipal, Karnataka, India -576 104 \\ ****Dr.Abhaya Kumar Mishra \\ Professor, Dept of RS and BK, Amrita School of Ayurveda, Amritapuri, Clappana P.O, \\ Vallickavu ,Kollam,Kerala- 690525
}

Article DOI: https://doi.org/10.36713/epra4645

\begin{abstract}
Dandruff (Darunaka) is a very common disease affecting most of the population in general. Darunaka can be compared with dandruff in modern medical science based on symptoms. Even though there are many anti-dandruff products available in the market, they are of high cost, low efficacy and some side effects. So there is a need for simple cost-effective herbal remedy for treating this condition. Hence in this study, a simple remedy is formulated in the form of ointment (Malahara). Dhurdhura patradi kera taila, the antidandruff oil was converted to ointment form by adding beeswax. It was anticipated that the addition of beeswax will enhance the effect of medicine because of its skin protective effect. Considering all the above-mentioned concepts, a study has been conducted and formulated a new Dosage modality (Kalpanabheda), Dhurdhurapatradi Malahara and studied its effect on Dandruff.
\end{abstract}

KEYWORDS: Darunaka, malahara, Dhurdhurapatradi kera, Dandruff, Squamometry.

\section{INTRODUCTION}

Dermatology is an essential part of general medicine, which is one of the sense organ covers the whole body, It is observed that diseases of the skin are common. The disease of the skin accounts for a great deal of misery, suffering incapacity and economic loss. Skin disease is not physically as painful as other systemic diseases. But it creates great psychological melancholy suffering. Besides this, they are a great handicap in society. Dandruff is one of the cosmetic ailment with pruritus and peeling scalp skin, mainly due to Malassezia Fungi, Sebaceous secretion, and personal Sensitivity. It is commonly treated with antifungal shampoos ${ }^{1,2}$.

Clinical Diagnosis with the type of histopathology confirmation if necessary in the management of dandruff. The differential diagnosis makes out among atopic dermatitis, lichen planus, Pityriasis rubra pllaris, Seborrheic dermatitis, Lichen simplex chronicus, Drug eruptions, cutaneous T-cell lymphoma, Pitryriasis rosea, Relter's disease, 


\section{EPRA International Journal of Research and Development (IJRD)}

Volume: 5 | Issue: 6 | June 2020

- Peer Reviewed Journal

Superficial fungal infections, Erythrama, aclinic keratosis, Subacute cutaneous lupus erythematosus,

Secondary syphilis. In pharmaceutical science pharmaceutical dosage modalities are of three types, they are solid, semi-solid, and liquid dosage forms. Ointments (Malahara) ${ }^{3,4}$, falls under semisolid dosage form. This preparation mainly needs three ingredients, an oil base, a binding agent and ingredients in powder form. These are the soft semisolid preparations, used for external application to the skin or mucous Membrane. Here, the medicaments will be dissolved or suspended or emulsified in the base. Ointments are used as emollients or protective agents to the skin or as vehicles for the topical application of medicinal substances. The absorption of medicaments by the tissues from the ointments, applied to the skin depends upon different factors. Properties soft he drugs incorporated. Properties of the base, used in the formulation. Condition of the patient's skin.

Site of application. Duration of application. These semi-solid dosage modalities exclusively meant for external application, commonly known as Malahara $^{5}$ kalpanas are the unique medicinal preparations In Ayurveda which were introduced first in Ayurveda by Scholar Yogaratnakara. Daruanaka malahara is available, such kind of preparations for Darunaka $^{6,7}$. This study was conducted to evaluate the efficacy of Daruanaka malahara on Dandruff. The present study includes Pharmaceutical study, analytical study.

\section{PHARMACEUTICAL STUDY}

It was prepared in the pharmacy of Department of Amrita School of Ayurveda. The main ingredients like fresh juice of Datura metal (Dhattura leaves), a paste of D. metal, Coconut oil and Beeswax. The seeds of D.metal was purified by using milk as mentioned in Ayurvedic classics. Then Oil (Dhurdhurapatradi kera taila ) was prepared as according to the Ayurvedic treatise Sahasrayoga. An ointment is prepared by using this oil ( 5 parts of taila and 1 part of beeswax) were used for preparation.

\begin{tabular}{||l|l|}
\hline Kalka (Shodhita Dattura Beeja) & $620 \mathrm{gm}$ \\
\hline Sneha (Narikela Taila) & $2.5 \mathrm{Litres}$ \\
\hline Dravadravya (Dhattura Patra Swarasa and Water) & $10 \mathrm{Litres}$ \\
\hline The total quantity of Dhurdhura Patradi Kera Taila obtained & $2.380 \mathrm{Litres}$ \\
\hline Loss & $120 \mathrm{ml}$ \\
\hline \hline Beeswax & $440 \mathrm{gm}$ \\
\hline Dhurdhura Patradi Kera Taila & $2200 \mathrm{gm}$ \\
\hline The total quantity of Malahara obtained & $2636 \mathrm{gm}$ \\
\hline Loss & $4 \mathrm{gm}$ \\
\hline
\end{tabular}

Table 01: Amount of ingredients and finished product while preparing Dhurdhurapatradi Kera Taila \& Dhurdhura Patradi Malahara

\section{ANALYTICAL STUDY}

Physicochemical analysis of Dhurdhurapatradi malahara was conducted in the quality control lab of
Dept. of Rasashastra \& Bhaishajyakalpana, Amrita School of Ayurveda. 


\begin{tabular}{||l|l||}
\hline Color & Pale Yellow \\
\hline Odour & Characteristic \\
\hline Taste & NA \\
\hline State & Soft Waxy Solid \\
\hline Loss on drying & $0.52 \%$ \\
\hline Congealing Range & $50-56^{0} \mathrm{C}$ \\
\hline Specific Gravity & 0.930 \\
\hline Saponification Value & $181.53 \mathrm{mg} / \mathrm{g}$ \\
\hline Peroxide Value & $4.495 \mathrm{Meq} / \mathrm{kg}$ \\
\hline Acid Value & \multicolumn{1}{|c||}{$3.3251 \mathrm{mg} / \mathrm{g}$} \\
\hline
\end{tabular}

Table 02: Analytical study result of Dhurdhura Patradi Malahara

\section{METHODOLOGY}

Dhudhurapatradi kera taila was prepared according to the reference of Treatise Sahasrayoga and Sharngadhara Samhita, in case of fresh juice (swarasa) 4 parts of water has to be added for preparing oil (taila). So considering these things, 620 gm D.meatal paste ( Dhattura beeja kalka), 2.5 litre's of Coconut oil (narikera tail) combination10 litres of D.metal juice and 8 lites of water (dravadravya )(2-litre dhattura swarasa +8 litres water) was added. Taila was prepared in the lab until getting oily consistency (taila paaka). Finally, the taila was taken and filtered. 2.380 litres of Dhurdhurapatradikera taila was obtained and $120 \mathrm{ml}$ loss was noticed. After preparing taila, malahara was prepared. As there is no direct reference of Dhurdhurapatradi malahara, it was prepared by the general method told for Malahara Kalpana in Rasatarangini. According to the ratio told in Rasatarangini, 1 part beeswax and 5 parts Dhurdhurapatradikera taila was added. So as per the ratio, 440gm of beeswax and $2200 \mathrm{gm}$. of Dhurdhurapatradi kera taila was taken. After heating the taila, the beeswax was added and stirred well. After complete melting of beeswax, the preparation was taken from the stove and filtered in heat state itself. $2636 \mathrm{gm}$. of malahara was obtained

\section{Discussion on an analytical study}

In Dhurdhurapatradi malahara, the organoleptic characters and physicochemical analyses like acid value, saponification value, specific gravity, LOD, congealing range, peroxide value were conducted. Since this is a new product, no previous analytical study has been conducted. So considering the standards of raw materials of the formulation, the results were found to be satisfactory.

\section{DISCUSSION}

So many examples can be given in support of that stated traditional preparations. As well as the drug, dosage and the vehicle the present global scenario ourselves without losing the traditional values and their entity concerning good manufacturing practices (G.M.P.). To evaluate the pharmaceutical standard product profile from raw material to finished product, a standard operative procedure (S.O.P.) is necessary nowadays. Ancient texts are given with proper guidelines for the pharmaceutical procedures with the light of micro to macro levels of the product reference to the bioavailability of the medicament. Now, in the modern age of science and technology, it is very difficult to meet the demand of the society. Many body systems come together in synergy. Skin forms about $1 / 8$ th of total body mass. It carried out biochemical, immunological and endocrinal etc. it provides individual identity in the society. As being the biggest organ of the body and being the surface it is directly exposed towards microorganism by hampering of the beauty of the person. It creates social, psychological impairments. Finally Part deals the summary of the whole study in short and the conclusion drawn is presented.

\section{CONCLUSION}

It was easy for preparation, application and transportation. The medicine was cost-effective also. The word Malahara or Malhama is derived from the Unani system of medicine. It derives its name as it removes residue (Mala) from wounds (Vrana), abscess (Vidradhi) etc. This is similar to ointments in contemporary pharmaceutics science. It is the ointment preparation which has beeswax and oil mixture, as the basic constituent. The additional 
constituents may include herbal, metal, or mineral origin substances subject upon the usage. Malahara has a property like Oelation (Snehana), and Healing (Ropana)

\section{REFERENCES}

1. Dr. Raveendra Angadi, A Text Book of Bhaishajya Kalpana Vijnana Pharmaceutical Science, Chapter 33, Chaukhambha Surabharati Prakashan, Varanasi, Reprint 2011, Page No. 319.

2. Harding CR, Matheson JR, Hoptroff M, Jones DA, Luo Y, Baines FL, Luo S. A high glycerolcontaining leave-on scalp care treatment to improve dandruff. Skinmed. 2014;12(3):155-61.

3. Cooper and Guns Dispensing for pharmaceutical student, 12th Edn, CBS Publishers

4. Dr K. R. Ramachandra Reddy. Bhaishajya Kalpana Vijnanam. Second edition. Varanasi: Chaukhamba Sanskrit Bhawan, 2008; 8: 470.

5. Vaidya Jadvji Trikamji Acharya(ed), Su $\div$ ruta Samhita, Varanasi, Chukhambha Sanskrit Sansthan, Reprint 2012, Chapter 13, Shloka No. 35, Page No. 322.

6. Krishnandji Maharaj, Rasatantrasara va Sidhaprayogasangraha, $1^{\text {st }}$ edition, Rajasthan, Krishna Gopal Ayurveda Bhawan; 2006; Page No. 863.

7. 7.Krishnan Vaidyar KV, S.VGopalapillai, Sahasrayogam, Alappuzha, Vidyarambham publishers, 27th edition, August 2007, Page No. 287. 